\title{
Anticipated Capitalization of the Santiago Metro System on Housing Prices
}

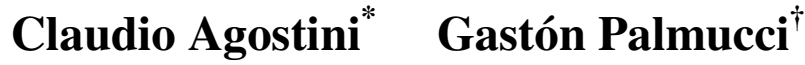

\footnotetext{
* Departamento de Economía, Universidad Alberto Hurtado, Erasmo Escala 1835, Santiago, Chile. Te: (562) 6920265. Fax: (562)6920303. E-mail: agostini@uahurtado.cl

${ }^{\dagger}$ Tribunal de Defensa de la Libre Competencia. E-mail: gpalmucci@tdlc.cl
} 


\begin{abstract}
Housing units with closer access to public transportation enjoy a higher market value than those with similar characteristics but poorer access. This difference can be explained by the less expensive cost of transport to the main workplaces and shopping areas in town. For this reason, investments in public transport infrastructure, for example, building a new metro line, are capitalized totally or partially on land property and housing prices.

This work analyzes empirically the degree of capitalization on housing prices when the new Line 4 of the Santiago de Chile Metro System was built. In particular, and given that the new line started operating in December 2005, the degree of anticipated capitalization on housing prices at the moment of announcing construction of Line 4 and at the moment of informing on the basic engineering to determine the location of the stations has been estimated.

A unique data base has been used, containing all home buying and selling operations in the Greater Santiago between December 2000 and March 2004. The results show that the average apartment price rose between $3.3 \%$ and $4.4 \%$ as a consequence of having announced the construction, and between $4.5 \%$ and $5.7 \%$ after information on the location of the stations was made known. This increase was not distributed evenly but depended on the distance to the closest station.

An indirect effect of this kind of capitalization is that property tax collection increases if landed property is reassessed according to the price rise. This effect is not negligible in magnitude and could stand for a minimum between $14 \%$ and $20 \%$ of investment in the new metro line, which gives way to an interesting discussion with respect to the form of financing the metro network extension.
\end{abstract}

Key Words: Metro, Apartment Prices, Anticipated Capitalization

Classification JEL: H54, R21, R53 


\section{Introduction}

Investing in public transport infrastructure bears a strong influence on urban development patterns and on house development market share distribution. Building or improving highways and mass public transport bears influence on the way demand and supply perform concerning location for residential, business or industrial use.

One of the effects that economic theory predicts with respect to the benefits of the different facilities and public transport services is that the latter capitalize totally or in part on land property and housing prices.

Despite the predictions of economic theory, broadly speaking, there is no consistent relationship between proximity to transport lines and property prices. For instance, the studies by Debrezion, Pels and Rietveld (2003), Dewees (1976), Grass (1992), Bajic (1983), Voith (1991) and Al-Mosaind et al. (1993) have found positive effects in the case of trains and subways used in different cities of the USA and Canada. On the other hand, the works by Dornbusch (1975), Armstrong (1994), Bowes and Ihlanfeldt (2001) show negative effects for trains. Gatzlaff et al. (1993) have found no evidence concerning the effects of having announced the new train system in Miami.

There is little empirical evidence in the case of anticipated effects of building public infrastructure. However, such evidence shows there is a certain degree of significant capitalization before a new facility or transport system starts operating (McMillen and McDonald (2004), Damm et al. (1980) and McDonald and Osuji (1995)).

In the case of Santiago de Chile, the metro system constitutes one of the most important investments in public transport infrastructure; the government decided that in 2001 the system would be enlarged significantly, extending two of the already existing lines and building a new one.

The purpose of this work is to identify the degree of capitalization a new metro line has on the house prices of the suburbs the new line will serve. 
With a unique data base and a methodology that combines hedonic regressions with an average treatment effects estimation, especially the degree of capitalization of access to the Santiago metro on house prices has been analyzed, as the result of building a new line. Because this new line started operating in December 2005, the estimated effect on property prices corresponds to the capitalization of the present value of future benefits granted by access to the system thanks to the soon operating new line.

The results show an important effect of anticipated capitalization as the consequence of building the new Line 4 of the Santiago Metro. The average price of apartments rose between $3.3 \%$ and $4.4 \%$ after construction was announced, and between $4.4 \%$ and $5.7 \%$ after the basic engineering project showing the location of the stations was made known. The capitalization degree is not homogeneous and, as expected, depends on the distance to the closest station. For an apartment located at a distance shorter than 200 meters the average price increase is $3.7 \%$ after announcing construction, and $4.68 \%$ after knowing the basic engineering project, while for a flat located between 600 and 800 meters away, the average price rise is $2.23 \%$ and $3.34 \%$ respectively.

The content of this article is dealt with as follows: in section 2, there is a brief description

of the Santiago Metro System, particularly, with respect to the new Line 4 construction; in section 3, a simple capitalization model is introduced; section 4 discusses identifying the metro system effect on house prices; in section 5 , the data used is described; in section 7 , the empirical results are shown and discussed; the conclusions are found in section 8.

\section{The Santiago Metro System and New Line 4}

In 1969, the Santiago metro network was designed as the central axis of the city transport system. The master plan included 7 lines which would be built following demand evolution. In 1975, the first section Moneda-San Pablo started operating; it was Line 1. Later on, Line 1 was extended to Escuela Militar in 1980 and Lines 3 and 5 were built; they started operating in 1987 and 1997 respectively. These three lines actually in operation cover $40.2 \mathrm{~km}$ railways, 52 stations, and in 2004, an average 866,700 daily travels were registered on weekdays. The 
following map shows the location and scope of the Santiago Metro Lines.

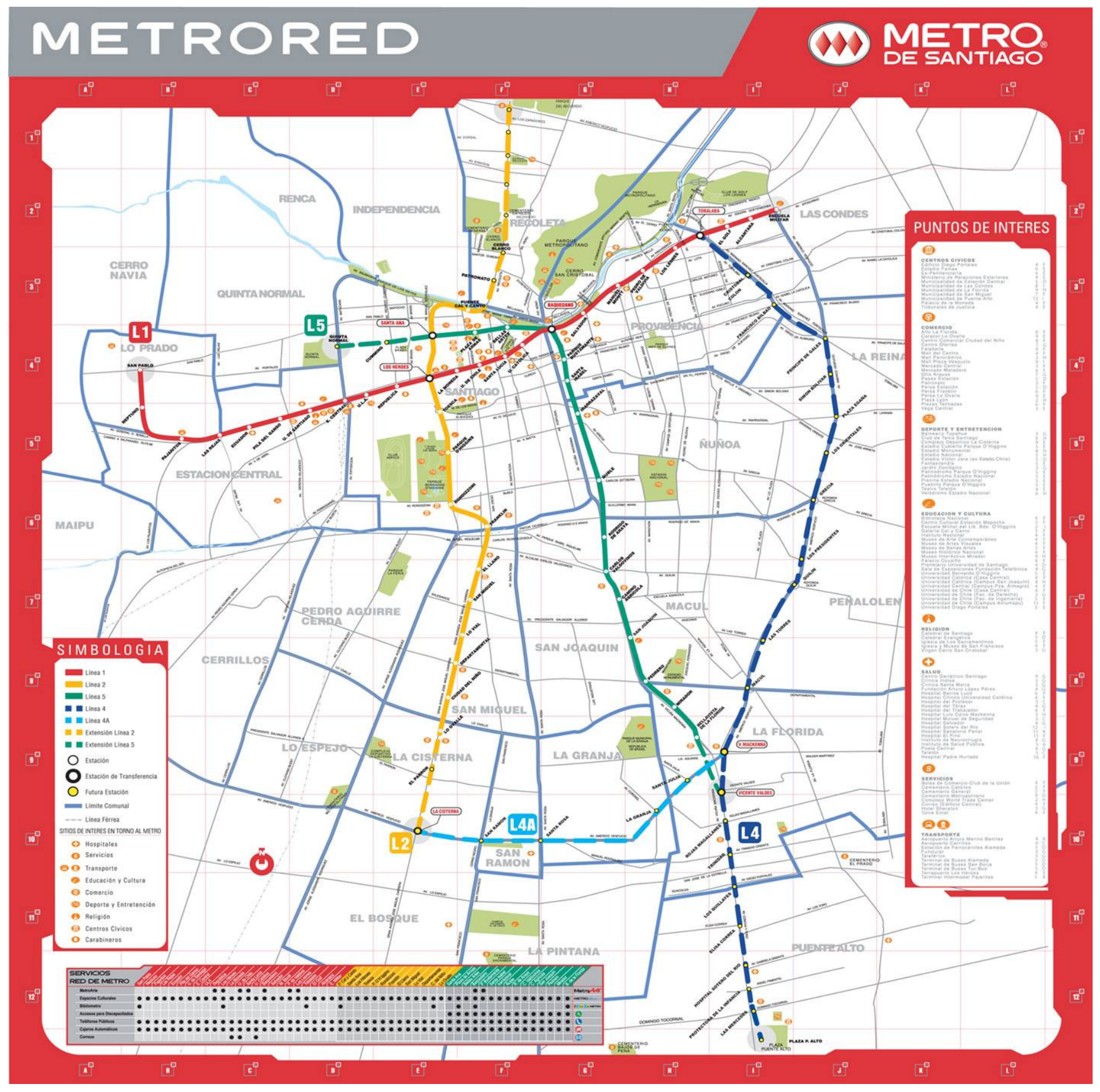

In May 2001, the government announced a new investment plan to solve the urban public transport problems in the city of Santiago. This plan, called Transantiago, means a re- 
organization of public transport through an integrated transport system with new buses, separate bus lanes and the metro network. ${ }^{1}$

The metro plays a primary role as articulator of the new public transport system; this is the reason why the Transantiago Plan involves important investments to improve and extend the metro network. In the short term, investments in the metro system consisted in extending Lines 2 and 5 and building Line 4 . The extensions to Lines 2 and 5 have been operating since the fourth quarter and the first four months of 2004, respectively; Line 4 is under construction and was expected to start partially operating in December 2005, and to be totally in operation in March 2006.

The project to extend Line 4 (Tobalaba-Vespucio-Puente Alto) involves $33 \mathrm{~km}$ railways and is divided into a main and a secondary sections. The main one starts at Plaza de Puente Alto and reaches the interconnection Tobalaba with Providencia, where there is connection with Line 1. The other section is extended along Américo Vespucio, between Vicuña Mackenna and Gran Avenida, where it connects with Line 2. The length of the main section is $24.4 \mathrm{~km}$ and covers 21 stations while the secondary section is $8.7 \mathrm{~km}$ long, with 6 stations $^{2}$. Demand projections reflect an increase in the average daily circulation flow of some 324,000 passengers; that is to say, $34.7 \%$, of the present traveling figures.

\section{Public Goods, Transport Cost and Housing Prices}

The characteristics associated with a housing unit and its location determine the prospective buyer's acceptance of the price to be paid for it. Location bears a fundamental effect for two reasons: access to public goods and transport cost.

In the first place, location determines the level of the local public goods the residents can

\footnotetext{
${ }^{1}$ The purpose of the government with the Transantiago Plan is to generate an efficient public transport that may reduce traffic jams and air pollution. Additionally, by using all available public transport means in an integrated manner, user quality service should improve.

${ }^{2}$ Including extensions of Lines 2 and 5, 38.6 Km and 33 stations would be added.
} 
consume. According to such characteristics, the market price of a housing unit reflects the marginal value to be paid for by all potential purchasers of units located in an area with access to a set of public goods (Yinger (1982), Rubinfeld (1987)). The degree of heterogeneity in the preferences of local public goods determines the degree of capitalization, but empirical evidence shows that its average value tends to capitalize importantly on housing prices ${ }^{3}$.

Secondly, the location of a housing unit determines the cost of transport the residents incur in to travel to their work and study places. Following the characteristics of a given unit and the level of public goods the residents can have access to, market price reflects the time and distance to the main job markets and to goods exchange places in a city (Von Thünen (1863), Alonso (1964), Mills (1967) and Muth (1969)).

New Line 4 is a semi-public good that reduces travel cost to the main workplaces and shopping centers of Santiago. For the two reasons above mentioned, one of the expected effects is a rise of housing demand in the geographical areas close to new Line 4 stations. Because land property supply in the relevant area is fixed in the long term, a demand rise should reflect an increase of land prices and housing units located near Line 4 stations. This increase would depend on the distance of the different housing units and properties to the new metro stations.

\subsection{Simple Capitalization Model}

A simple model is introduced in this section, adapted from Alonso's (1964), to show the consumer location decision explicitly in terms of the metro network.

The problem facing each consumer is to maximize utility, in terms of the size and location of the unit, subject to budget constraints related explicitly to transport cost and its effects on house prices. This maximization can be expressed as follows:

\footnotetext{
${ }^{3}$ See Gramlich y Rubinfeld (1982).
} 


$$
\begin{aligned}
& \underset{m, d, x}{\operatorname{Max}} V(m, d, x) \\
& \text { s.a. } \\
& Y=x+P(d) m+T(d)
\end{aligned}
$$

where $m$ is the property average size, $d$ is the distance from the property to the closest metro station, $x$ is a compound good made up of all other staples an individual consumes, $P(d)$ is the price per property square meter and $T(d)$ is the transport cost function. The inclusion of distance in an individual's utility function captures the disutility (leisure) for the consumer to reach the closest metro station.

Let us assume that function $V$ is continuous, twice differenciable and strictly quasiconcave, increasing in $m$ and $x$, and decreasing in $d$. Additionally, $\partial P(d) / \partial d<0$ y $\partial T(d) / \partial d>0$. The first order conditions for.this maximization problem are:

$$
\begin{aligned}
& V_{m}-\lambda P(d)=0 \\
& V_{d}-\lambda\left[P_{d} m+T_{d}\right]=0 \\
& V_{x}-\lambda=0 \\
& Y-x-P(d) m-T(d)=0
\end{aligned}
$$

From equations (2) and (4), one of the equilibrium location conditions can be obtained:

$$
\frac{V_{x}}{V_{m}}=\frac{1}{P(d)}
$$

This first equilibrium condition establishes that the marginal ratio the consumer is willing to accept to substitute property square meter consumption, $m$, with consumption of other goods, is equal to the relative price. Relative prices depend on the distance to the transport service under study.

From (3) and (4), a second equilibrium condition is obtained: 


$$
P_{d} m=-\left[T_{d}-\frac{V_{d}}{V_{x}}\right]
$$

This second condition establishes that the marginal value the individual would accept to pay per property square meter decreases as transport cost increases and rises when disutility causing longer traveling diminishes.

This simple model shows that, from a theoretical viewpoint, there would be a negative relationship between house prices and distance to the closest metro station. This houseprice/distance relationship is not necessarily monotonically decreasing. The reason for it is that the metro station may have two possible impacts: on the one hand, a means of transport is made available, which produces a direct positive effect because the residents in the neighborhood reduce transport cost; on the other, the metro station generates a host of effects indirectly associated, for instance, with better lighting in the area, increased circulation of people, higher noise level, more commercial activities, etc. The net impact of this host of indirect effects is ambiguous because some of them may impact on the price of the housing units nearest to the station positively, while others may do so negatively. Consequently, the house prices/distance to the closest metro station relationship may have non linearities or it may even be some of the function components be increasing.

Although this simple model offers a forecast empirically testable with respect to the impact distance to the metro station on property value may have, other factors also affecting housing prices and included in the consumer decisions have not been considered.

Empirical evidence shows it is of weight to include as determinants of house prices the housing unit characteristics (number of rooms, age, square meters, and others), the neighborhood characteristics (delinquency rate, average income, quality schooling in the area, etc.) and property tax and local public goods supply (garbage collection, police patrolling, hospitals, and others) ${ }^{4}$.

In broad terms, the house price equation to be estimated is:

\footnotetext{
${ }^{4}$ See, for example, Vesalli, (1996) and Gibbons and Machin (2005).
} 
where the dependent variable $P(i)$ is the selling property price i, $X(i)$ the housing unit structural assets matrix (including surface, number of bathrooms, bedrooms, etc), $L(I)$ is the matrix reflecting the neighborhood and location features other than access to mass public transport (public goods, green areas, shops, schools, clinics), $D(i)$ is a matrix for the relevant variables related to access and, lastly, $\varepsilon(i)$ is the error.

The estimation of equation (8) is equivalent to a hedonic price regression (Rosen (1974), Bartik (1979) and Freeman (1979)), which captures the average value consumers give to each particular housing unit characteristic and its surroundings 5 .

\section{Identification}

A hedonic price estimation as in equation (8) allows to estimate consumer marginal value of access to the metro station. For this reason, it is enough if matrix $D$ is defined as the distance or the time it takes to reach the nearest station. Then, access capitalization can be identified by estimating how housing prices vary as distance to the station increases or by estimating house price differences within the range of the metro stations in relation to those not within it. This exercise should show the impact of the metro lines already operating, as Lines 1,2 and 5.

However, the purpose of this study is to estimate the capitalization of Line 4 not yet in operation. In this case, the point of interest is to estimate the degree of anticipated capitalization on the housing units associated to the future benefits the new line will bring about. To this effect, the different stages for developing Line 4 must be first identified:

1. General Layout $(t=1)$ : The general layout of the metro network has been known since 1969. However, it is not entirely certain when the investments will be made and whether the original layout will be followed.

\footnotetext{
${ }^{5}$ In equilibrium, the estimated coefficients for a characteristic may be interpreted as the acceptance to pay for a marginal increase of said characteristic.
} 
2. Specific Announcement ( $\mathrm{t}=2)$ : In May 2001, the government announced the extension of Lines 2 and 5 and creation of new Line 4 to Puente Alto. However, the location of the stations is not known and there may be some uncertainty concerning the implementation of the project because financing was still being discussed.

3. Basic Engineering Project: In December 2001, the location of the future Line 4 metro stations is made known.

4. Start of Construction ( $\mathrm{t}=3$ ): In July 2002, construction of Plaza Puente Alto Station was started.

5. Opening ( $\mathrm{t}=4)$ : Line 4 should start operating partly in December 2005, and completely since 2006.

6. Operating Consolidation ( $\mathrm{t}=5$ ): After a few months in operation, consumers collect more information concerning quality service, frequency and prices.

If consumers have rational expectations, capitalizing the benefits that the new Line 4 may bring about should take place at the moment of announcing construction. However, the degree of house price adjustments also depends on the expected risk of the construction not occurring and of uncertainty concerning location of the stations.

In order to discuss identification of the impact of the metro system on housing prices, let us take only one stage; for example, announcing the construction of the new metro line. Let us define the $t-1$ period as the ex ante situation before announcing construction and with $t$ the ex post period. If, in effect, some capitalization did occur, and checking with all other relevant factors, it would be seen that the price of a housing unit i increases from $P_{i t-1}$, at $t-1$, to $P_{i t}$, at $t$. To quantify the externality value generated by building the metro line on a given property price, the mentioned price range should be determined if the case under study did not exist; that is to say, it is necessary to imagine a counterfactual ${ }^{6}$ situation. As it is not possible to observe the same housing unit in both conditions, it is necessary to find one with similar characteristics (home type, covered square meters, number of bedrooms and bathrooms, orientation, etc) in an area not within the range of the metro layout, called the control property unit. The estimator to calculate

\footnotetext{
${ }^{6}$ See Rubin (1974); Rosenbaum and Rubin (1983); Angrist, Imbens, and Rubin (1996); and Heckman, Ichimura and Todd (1997).
} 
the externality is the difference in difference estimator from the following equation ${ }^{7}$ :

$$
P(i)=\theta+\pi X(i)+\varpi t(i)+\delta L(i)+\alpha A T E(i)+\tau D(i)+\varepsilon(i)
$$

where

$$
\begin{aligned}
\alpha=\{E[P(i, t) \mid X(i), A=1] & \left.-E\left[P^{c}(i, t) \mid X(i), A=0\right]\right\}- \\
& \left\{E[P(j, t-1) \mid X(j), A=1]-E\left[P^{c}(j, t-1) \mid X(j), A=0\right]\right\}
\end{aligned}
$$

The interpretation of this estimator, obtained by modifying the hedonic regression specified in (7), is the following: the average change in the distance marginal value from the housing unit to the metro station with respect to the average change in the marginal value of those units not within the metro range.

\section{Data}

The data base from the Conservador de Bienes Raíces de Santiago ${ }^{\mathbf{8}}$ (Property Registrar of Santiago) was used for the empirical analysis. This is the only data base containing all Real Estate Property transactions made in the Greater Santiago between December 2000 and March 2004. Each observation contains the selling house price, a set of variables describing the physical attributes of the property and the geographical location (East-North coordinates).

Regrettably, information on the physical attributes of housing units is very limited. For this reason, it was decided that only the data concerning apartment transactions would be used, which show detailed information of the characteristics. There are 20,900 recorded transactions in the counties of Providencia, Las Condes, La Reina, Peñalolén, Macul, Nuñoa and La Florida over

\footnotetext{
${ }^{7}$ Bajic (1983), Dewees (1976), Gatzlaff and Smith (1993), Lee (1973), McDonald and Osuji (1995) and McMillen and McDonald (2004), although these works differ concerning model specification, in general the idea is to compare changes in house prices in the area within reach of the metro impact with the changes in the control housing units not in the scope of the metro impact.

${ }^{8}$ The Conservador de Bienes Raíces de Santiago (Property Registrar of Santiago) records all the transactions concerning housing, offices and land property made in the Greater Santiago. This data base was kindly provided by Mapcity S.A. .
} 
this period.

For each apartment, the distance to each of the 44 metro stations was calculated (19 of them belonging to Lines 1, 5, and 25 related to the future Line 4) as is next described.

1. By using Mapcity, the digital map of Santiago, the metro stations corresponding to Lines 1, 4 and 5 were located ${ }^{9}$.

2. The Euclidian distance $(d)$ between each home and the metro stations was calculated $^{10}$ :

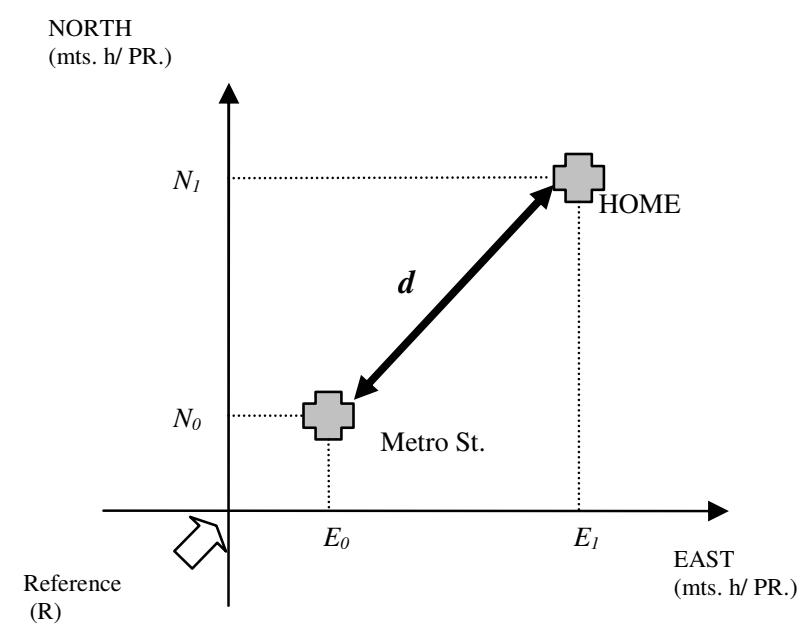

Over the 20,900 total apartments on the data base, there are 6907 units for which the shortest distance to a station coincides with a station corresponding to new Line 4

Table 1 shows a summary statistics of the variables used in the estimation. The dependent variable is the apartment price measured in U.F. (Unidades de Fomento) ${ }^{11}$. As independent variables, three groups of variables have been used.

\footnotetext{
${ }^{9}$ The location process means simply to assign a pair of East-North coordinates to each observation.

${ }^{10}$ Distance Home- Metro Station $=$

Distancia Vivienda - Metro $=d=\sqrt{\left(E_{1}-E_{0}\right)^{2}-\left(N_{1}-N_{0}\right)^{2}}$

${ }^{11}$ Unidades de fomento (U.F.) is one of the readjustment systems authorized by Banco Central de Chile (Central Bank of Chile) 1 UF equals CH $\$ 17,700$ and US\$ 32.8 to September 2005. It is used to index prices relative to inflation. To October 2006, one U.F. equaled CH\$18,417.

Unidad de Fomento (U.F.) es uno de los sistemas de reajustabilidad autorizados por el Banco Central de Chile; 1 U.F. es equivalente a \$ chilenos 17.700 y US\$32,8 a fecha septiembre de 2005.
} 
Table N 1

\begin{tabular}{|c|c|c|c|c|}
\hline Variable & Media & $\begin{array}{l}\text { Standard } \\
\text { Deviation }\end{array}$ & Mín. & Max \\
\hline Price (UF) & 2.688 & 1.387 & 201 & 29.804 \\
\hline Covered Surface (mts. ${ }^{2}$ ) & 84 & 32 & 16 & 508 \\
\hline New Home & 0,57 & 0,50 & 0 & 1 \\
\hline Benefit DFL2 & 0,05 & 0,21 & 0 & 1 \\
\hline Bedrooms & 2,66 & 0,81 & 1,00 & 5 \\
\hline Bathrooms & 2 & 1 & 1 & 4 \\
\hline Parking & 0,59 & 0,49 & 0 & 1 \\
\hline Basement & 0,69 & 0,46 & 0 & 1 \\
\hline Elevator & 0,71 & 0,45 & 0 & 1 \\
\hline Closest Clinic (meters) & 948 & 963 & 9 & 4.992 \\
\hline Closest Hospital (meters) & 2.656 & 1.111 & 386 & 6.482 \\
\hline Closest School (meters) & 252 & 165 & 6 & 1.020 \\
\hline Closest green (meters) & 295 & 195 & 15 & 1.251 \\
\hline Street & 0,59 & 0,49 & 0 & 1 \\
\hline Avenue & 0,38 & 0,49 & 0 & 1 \\
\hline Change in Housing Stock & 28.337 & 1.716 & 24.046 & 31.903 \\
\hline Closest Metro Station (meters) & 1.516 & 1.113 & 8 & 4.939 \\
\hline Announcement & 0,92 & 0,28 & 0 & 1 \\
\hline Basic Engineering & 0,76 & 0,43 & 0 & 1 \\
\hline D1000 & & & 0 & 1 \\
\hline
\end{tabular}

Firstly, there is a set of variables which capture the structural characteristics of each apartment: covered surface in square meters, number of bedrooms, number of bathrooms, whether there is a basement in the building, elevator, parking, type of apartment (new or second hand), whether it enjoys fiscal benefit DFL 2 and if the building is located in a street or an avenue.

Secondly, there is a set of variables which capture access to public and semi-public goods. Along with distance to the metro station, and using the same procedure already introduced, the closest distance between each unit and a school, hospital, clinic and green area were calculated. 582 schools, 8 hospitals, 52 clinics and 756 existing green areas in the relevant communes were taken.

In the third place, a set of dummies equivalent to fixed effects per commune, per month 
and per annum has been taken.

Finally, to capture the degree of the metro anticipated capitalization on house prices, there is a set of dummy variables that help isolate the value of access to the stations over different relevant periods at different distances.

The variable Announcement captures the change in the average housing prices as a result of announcing construction of the new metro line, and the expected sign is positive.

As mentioned before, at the moment of announcing the construction of Line 4, the different stations had not yet been defined. Additionally, price adjustments in the property market may probably lag behind because there is a house-hunting cost and consumers should match sellers. That is why a considerable degree of capitalization may have occurred after the announcement. The variable Basic Engineering captures the effects of having given information on the engineering, in October 2001 (5 months after the announcement), after the location of the stations had been known.

Additionally, the variables Announcement and Basic Engineering interact are interacted with the variable Distance to the Metro to capture the change in the apartment price, according to closest distance to a station, which is the result of announcing construction or of informing on Line 4 basic engineering. Although it is expected that property value decreases as distance to a station increases, it may be that for the apartment units close to the stations the value goes up as a farther distance makes them less noisy and the circulation of people and shopping diminish (Dueker, Chen y Rufolo (1997)).

The potential problem these two variables show is that distance of the apartments for which the metro system is irrelevant are also considered. For example, for a flat located $2 \mathrm{~km}$ away from the nearest station, it is unlikely that construction announcement or basic engineering information had had any impact on prices. The expected bias derived from including distance for those units is downward; that is to say, the estimated coefficients may show a lower property value rate as distance to the metro station becomes longer. In order to eliminate such potential bias, the interaction of the variables Announcement and Distance with the dummy D1000 variable that distinguishes between the apartments within a $1000 \mathrm{~m}$ range to each station from the 
farther away units have been considered ${ }^{12}$. This last variable is a difference in difference estimator, as the one mentioned in Section 4.

\section{Results}

Tables 2 and 3 show the results of equation (10) estimation when capitalization occurs after announcing construction of the new line and after the basic engineering project has been made known, respectively.

Four separate specifications have been considered in each case. Model 1 takes the closest distance to the station per se and interacted with the corresponding treatment dummy (Announcement and Basic Engineering). Model 2 additionally includes, in order to capture nonlinearities the interaction between the treatment dummy and the square meter distance. Model 3 takes the square meter distance and the interaction of the treatment dummy with distance in meters and with distance in square meters. Finally, model 4 with respect to model 3 adds the interaction of the closest distance to the station with the treatment dummy and a dummy equal to 1 if the apartment is located less than $1000 \mathrm{~m}$ away from the station, and equal to 0 on the contrary.

The specification of the first three models helps to capture the effects of the construction announcement (or of the basic engineering information) on housing prices, depending on the closest distance between the housing units and the metro station. The fourth model specification helps to determine the degree of capitalization on the apartments which are located within the scope of direct impact of the new metro line.

In general terms, the results related to the characteristics of the units show the expected signs and are quite strong concerning the different specifications. The estimated coefficients for the variables covered surface, number of bathrooms, basement and brand-new unit are all positive and statistically significant. An additional meter surface and an extra bathroom are associated, on

\footnotetext{
12 According to Metro S.A. estimations, within the $5000 \mathrm{~m}$ to the station, around $50 \%-60 \%$ of the demand is captured, and within the $1000 \mathrm{~m}$ between $80 \%$ and $90 \%$.
} 
average, with prices above the $29 \mathrm{UF}$ and $144 \mathrm{UF}$, respectively. Similarly, a basement and a brand-new unit are linked, on average, to prices above 173 UF and 700 UF, respectively.

The estimated coefficient for the number of bedrooms is negative and statistically significant, which may appear as the opposite of what is expected. However, what the negative sign shows, by checking surface and number of bathrooms on the regression, is that the inclination to pay higher prices is directly related to larger living or dining-rooms, kitchen, or more bedrooms. The variables parking and elevator are not statistically different from zero.

The results concerning the impact access to some public goods have are not altogether satisfactory. The estimated coefficients for the variables measuring closest distance to a clinic, hospital or school are not statistically significant. There may be two alternative explanations in this respect. One of them is that the quality service is more important than the location distance. But when the variable measures distance from the apartment to the closest green area. the coefficient is indeed significant but with a positive sign, which is contrary to expected. A possible explanation may be that consumers do not judge quality or that they may prefer a larger though farther away green area to a closer small square. For some of the communes in the sample, some green areas constitute places associated to higher crime.

Changes in housing stock has a negative effect on apartment prices and is statistically significant; they reflect the impact higher supply has on the market equilibrium price.

Lastly, the effect of fiscal benefit DFL. 2 is statistically not significant. In this respect, it is important to remember that the sample period starts in December 2000, a moment when some of the fiscal benefits had been reduced. The greater effect occurred because dividend payments that may be income tax deductible reached a maximum 120 Unidades Tributarias Mensuales (UTM)* annually if the unit in the D.F.L. No 2 was purchased before 31 December 1999; 72 UTM if it was bought between 1 January and 30 September 2000; and 36 UTM if it was bought between 1 October and 30 June 2001.

* UTM (Unidad Tributaria Mensual) is a system used in the manner of the UF (Unidad de Fomento) quoted before, but related to taxes, to keep taxes indexed according to inflation. 


\subsection{Capitalization at Announcement}

Table 2 shows the results of the estimation, taking into consideration the construction announcement of new Line 4 as treatment variable. The coefficient of variable Announcement is positive and statistically significant in the 4 specifications. As can be seen in the table, the estimator point for the variable Announcement is found between 119UF and $160 \mathrm{UF}$, depending on the specification, which is equivalent to an average apartment value appreciation between $3.3 \%$ and $4.4 \%$.

The interaction of the variables Announcement and Distance has a negative impact on apartment prices and is statistically significant, showing an uneven distribution of access anticipated capitalization. Following theoretical forecasts, apartment value rises decrease as distance to the closest station becomes longer. The estimated coefficient shows the impact of the metro system decreases between 0,088 and 0,127 UF per each meter farther away the unit is located from the nearest station.

Table 2: Estimation for Line 4 Construction Announcement

\begin{tabular}{|c|c|c|c|c|c|c|c|c|}
\hline & (1) & & (2) & & (3) & & (4) & \\
\hline Surface & 29,1231 & * & 29,1264 & * & 29,1245 & * & 29,1683 & * \\
\hline Bedrooms & $-53,1601$ & ** & $-53,8956$ & ** & $-54,2966$ & $* *$ & $-53,8241$ & ** \\
\hline Bathrooms & 144,9697 & * & 145,5432 & * & 145,3796 & * & 144,4248 & * \\
\hline Brandnew unit & 702,2893 & * & 702,1810 & * & 702,2500 & * & 705,1322 & * \\
\hline DFL2 & $-43,6710$ & & $-46,3044$ & & $-46,9339$ & & $-48,1913$ & \\
\hline Parking & $-19,3390$ & & $-18,6115$ & & $-17,8348$ & & $-19,1403$ & \\
\hline Basement & 171,3244 & * & 172,6653 & * & 173,8318 & * & 171,8929 & * \\
\hline Elevator & $-3,0884$ & & $-0,8835$ & & 0,5363 & & 2,9816 & \\
\hline Avenue & 158,2917 & * & 164,1127 & * & 167,9563 & * & 159,9478 & * \\
\hline Street & 267,2855 & * & 272,0937 & * & 274,8061 & * & 271,1803 & * \\
\hline Clinic Distance & 0,0104 & & 0,0071 & & 0,0050 & & 0,0027 & \\
\hline Hospital Distance t & $-0,0149$ & & $-0,0198$ & & $-0,0198$ & & $-0,0201$ & \\
\hline School Distance & $-0,0121$ & & $-0,0156$ & & $-0,0180$ & & 0,0421 & \\
\hline Green Area Distance & 0,1929 & * & 0,1844 & * & 0,1799 & * & 0,1828 & * \\
\hline Change in Housing Stock & $-0,0134$ & * & $-0,0134$ & * & $-0,0134$ & * & $-0,0133$ & * \\
\hline Announcement & 138,1372 & * & 154,3929 & * & 119,0397 & * & 160,2813 & * \\
\hline
\end{tabular}




\begin{tabular}{|c|c|c|c|c|c|c|c|c|}
\hline Distance Announcement & $-0,1002$ & * & $-0,1274$ & * & $-0,0883$ & * & $-0,1051$ & * \\
\hline Distancia2 Announcement & - & & 0,0000 & & & & & \\
\hline Distance in meters & 0,0535 & * & 0,0575 & * & & & & \\
\hline Distance in $\mathrm{m}^{2}$ & & & & & 0,0000 & ** & 0,0000 & ** \\
\hline Distance D 1000 Announcement & & & & & & & $-0,0647$ & ** \\
\hline Constant & $-937,4802$ & * & $-950,6412$ & * & $-918,4153$ & * & $-946,3562$ & * \\
\hline Commune Dummies & $\mathrm{Si}$ & & si & & si & & si & \\
\hline Monthly Dummies & $\mathrm{Si}$ & & si & & si & & si & \\
\hline Annual Dummies & $\mathrm{si}$ & & si & & si & & si & \\
\hline $\mathrm{R}^{2}$ & 0.7154 & & 0.7154 & & 0.7154 & & 0.7155 & \\
\hline $\mathrm{F}$ & 475.99 & & 465.62 & & 473.22 & & 646.05 & \\
\hline
\end{tabular}

Model 4 offers interesting results; different from the other three models, it includes the variable D1000 interacted with the variables Distance and Announcement. As mentioned earlier on, this variable distinguishes units within a 1000m range concerning distance to each of the metro stations. Because the strongest impact occurs in the quoted range, this variable helps to distinguish a group of units with treatment from another group without treatment, and, then, it becomes a difference in difference estimator. The results of this model show a capitalization of 160 UF on the apartment value after construction of the new line has been announced. Capitalization grows the closer to the station the apartment is located; the unit price increases at a 0,065 UF rate per each additional meter closer to the station. It must be noted that this last effect is statistically non-linear because the coefficient for the square distance is statistically significant. However, the estimated coefficient is very close to zero.

\subsection{Capitalization at Basic Engineering Informing}

Table 3 shows the results of the estimation when the treatment variable stands for knowing the basic engineering project. As already mentioned, such knowledge gives certainty concerning the metro stations location. 
The coefficient of the Basic Engineering variable is positive and statistically significant. The estimator point reflects a capitalization between 161 and 206 UF, equivalent to an average increase between $4.5 \%$ and $5.7 \%$, higher than that estimated for the moment of announcing construction of new Line 4.

Just as with former results, the degree of capitalization depends importantly on closest distance to a station. The interaction of the Basic Engineering and Distance variables captures that effect and, as can be seen in the Table, the estimated coefficient is negative and statistically significant, and reflects lower price in a range between 0,061 and 0,139 UF for each additional meter farther away from the closest metro station.

\section{Table 3: Estimation at Basic Engineering Information Moment}

\begin{tabular}{|c|c|c|c|c|c|c|c|c|}
\hline & (1) & & (2) & & (3) & & (4) & \\
\hline Surface & 29,1227 & * & 29,1078 & * & 29,1364 & * & 29,1551 & * \\
\hline Bedrooms & $-52,9836$ & ** & $-54,0849$ & ** & $-53,6996$ & ** & $-53,3503$ & ** \\
\hline Bathrooms & 143,9272 & * & 146,0925 & * & 144,1968 & * & 143,7058 & * \\
\hline Brandnew Unit & 697,4616 & * & 699,1116 & * & 696,4032 & * & 697,2848 & * \\
\hline DFL2 & $-19,7578$ & & $-25,5256$ & & $-21,6497$ & & $-21,8592$ & \\
\hline Parking & $-18,6259$ & & $-16,7756$ & & $-17,9881$ & & $-18,6841$ & \\
\hline Basement & 174,1035 & * & 177,2257 & * & 175,1085 & * & 174,0034 & * \\
\hline Elevator & $-5,3244$ & & $-2,0426$ & & $-3,4978$ & & $-1,8076$ & \\
\hline Avenue & 161,4116 & * & 176,7520 & * & 165,4532 & * & 160,6796 & * \\
\hline Street & 270,9603 & * & 283,2493 & * & 274,8886 & * & 272,0019 & * \\
\hline Clinic Distance & 0,0143 & & 0,0039 & & 0,0124 & & 0,0117 & \\
\hline Hospital Distance & $-0,0160$ & & $-0,0274$ & & $-0,0227$ & & $-0,0227$ & \\
\hline School Distance & $-0,0163$ & & $-0,0239$ & & $-0,0182$ & & 0,0171 & \\
\hline Green Area Distance & 0,1864 & * & 0,1637 & * & 0,1804 & * & 0,1806 & * \\
\hline Change in Housing Stock & $-0,0115$ & ** & $-0,0115$ & ** & $-0,0115$ & ** & $-0,0115$ & ** \\
\hline Basic Engineering & 160,7279 & * & 206,0614 & * & 164,9638 & * & 188,5718 & * \\
\hline Basic Engineering *Distance & $-0,0612$ & * & $-0,1392$ & * & $-0,0645$ & * & $-0,0738$ & * \\
\hline Basic Engineering ${ }^{*}$ Distance ${ }^{2}$ & & & 0,0000 & ** & & & & \\
\hline Distance in meters & 0,0076 & & 0,0164 & & & & & \\
\hline $\begin{array}{l}\text { Distance in } \mathrm{m}^{2} \\
\text { Basic Engineering } \\
{ }^{*} \text { Distance }{ }^{*} \mathrm{D} 1000\end{array}$ & & & & & 0,0000 & & $\begin{array}{r}0,0000 \\
-0,0421\end{array}$ & ** \\
\hline Constant & $-983,9981$ & * & $-1.028,9350$ & * & $-983,0360$ & * & $-991,3707$ & * \\
\hline
\end{tabular}




\begin{tabular}{lcccc}
\cline { 2 - 4 } Commune Dummies & $\mathrm{Si}$ & $\mathrm{si}$ & $\mathrm{si}$ & $\mathrm{si}$ \\
Monthly Dummies & $\mathrm{Si}$ & $\mathrm{si}$ & $\mathrm{si}$ & $\mathrm{si}$ \\
Annual Dummies & $\mathrm{Si}$ & $\mathrm{si}$ & $\mathrm{si}$ & $\mathrm{si}$ \\
\hline $\mathrm{R}^{2}$ & 0.7154 & 0.7156 & 0.7154 & 0.7155 \\
$\mathrm{~F}$ & 477.26 & 464.86 & 477.75 & 467.57 \\
\hline
\end{tabular}

It must be pointed out that the results in Tables 2 and 3 are strong robust as concerns both the alternative specifications in each model and the more flexible structure errors. In particular, to rule out possible residual correlation problems between counties ${ }^{13}$, with SUR (Seemingly Unrelated Regressions) a commune equations system has been estimated. The Breush-Pagan test for independence of equations did not reject the hypothesis that the variance-covariance matrix of the system be diagonal.

Finally, Table 4 shows the average percentage changes in the apartment values as a result of having announced the new line construction and the basic engineering project considering distance to the closest station.

\section{Table 4: Effect on Average Apartment Prices according to Distance to Metro Stations}

\begin{tabular}{|l|ccccc|}
\hline & \multicolumn{5}{|c|}{ Distance } \\
\cline { 2 - 6 } & $\mathbf{0 - 2 0 0}$ & $\mathbf{2 0 1 - 4 0 0}$ & $\mathbf{4 0 1 - 6 0 0}$ & $\mathbf{6 0 1 - 8 0 0}$ & $\mathbf{8 0 1 - 1 0 0 0}$ \\
\hline$\Delta^{+} \%$ Announcement & $3,70 \%$ & $3,20 \%$ & $2,70 \%$ & $2,23 \%$ & $1,76 \%$ \\
$\Delta^{+} \%$ Basic & $4,68 \%$ & $4,23 \%$ & $3,78 \%$ & $3,34 \%$ & $2,90 \%$ \\
Engineering & & & & \\
\hline
\end{tabular}

Although the average impact on the apartment prices within range of new Line 4, between $2.9 \%$ and $4.7 \%$ according to distance, is important in magnitude, it is likely that said impact be still higher for two reasons: a) the new metro line will not yet be operating and, following conversations with some Development Agents, it is highly probable selling prices go up when the stations are actually operating; b) there is supporting theoretical and empirical evidence

\footnotetext{
${ }^{13}$ There may be, for example, some degree of space correlation between prices in neighboring communes.
} 
concerning the likelihood that a fraction of the metro impact be capitalized on the wages of the people living in the communes where the metro is operating (Roback, 1980 and 1982; Blomquist et al., 1988; Gyourko and Tracy, 1989 and 1991). Then, it may well be that the estimated capitalization on housing underestimate total capitalization as the result of building new Line 4 in the Santiago Metro System.

\subsection{Fiscal Effect of Capitalization}

One of the most important indirect effects which potentially metro capitalization on house prices may have is that as house prices increase property tax collection would also go up. For this effect to actually occur, it is required that the Internal Revenue Office reassess properties in the communes where the new line will be operating.

The change in tax collection $(\Delta \mathrm{R})$ may be calculated as

$$
\Delta R=\sum_{i=1}^{n} t_{v i} \times \Delta B I_{i}
$$

where $\triangle B I$ stands for the change on tax base and $t_{v i}$ is the tax rate, which is a function of the property value $^{14}$

Using the results from these estimations and equation (11), the potential changes in the tax base (fiscal assessed value) and in non-agricultural land payments have been estimated. To this effect, only the 3194 apartments located less than 1000 meters from the closest new Line 4 station have been taken.

In Table 5, the main results for each of the four models estimated are shown; it is assumed that the rise in each apartment fiscal assessment increases proportionately to the capitalization

\footnotetext{
${ }^{14}$ Non-agricultural areas destined to housing enjoy a land tax exemption amount of \$10,878,522 at 1 January 2005. The aliquot corresponding to non-agricultural land property destined to housing is $1.2 \%$ per annum, when the tax base is not in excess of $\$ 37,526,739$ at 1 January 2005 ; it is $1.4 \%$ per annum when the tax base is in excess of the quoted amount.
} 
brought about by announcing the basic engineering. In case I, it is assumed that the fiscal assessment rise is independent of the distance each apartment is located at from the closest station. In case II, it is assumed that the fiscal assessment rise considers the degree of capitalization depends on the distance between the apartment and the nearest metro station.

\section{Table 5: Percentage Change in Property Tax Collection}

\begin{tabular}{cccccc}
\hline$\Delta(\boldsymbol{\%})$ & $(\mathbf{1})$ & $\mathbf{( 2 )}$ & $\mathbf{( 3 )}$ & $\mathbf{( 4 )}$ & $\begin{array}{c}\Delta \\
\text { Sample } \\
\text { Mean }\end{array}$ \\
\hline \hline Taxpayers A Collection & $8.00 \%$ & $10.49 \%$ & $8.23 \%$ & $9.52 \%$ & $9.06 \%$ \\
Taxpayers B Collection & $6.03 \%$ & $5.90 \%$ & $6.14 \%$ & $7.08 \%$ & $6.29 \%$ \\
\hline
\end{tabular}

As can be seen in the Table, capitalization of the Metro value on house prices may bring about a rise between $8 \%$ and $10.5 \%$ in apartment tax payments in the sample if the assessed value does not take into account distance to the metro station; it is $6 \%$ and $7 \%$, if longer distance to the station means less capitalization.

The estimated increase in property tax collection reflects between $1.3 \%$ and $1.9 \%$ of the cost of investing in new Line 4. However, it should be noted that the estimated impact on tax collection has been calculated for an apartment sample of around $10 \%$ of all the apartments located within the range of new Line 4 stations. If the impact for the remaining $90 \%$ population (33,911 total apartments according to the 2002 census) is similar on average, the increase in total collection would be between 29,261 U.F. and 92,772 U.F. annually, which means between 14.5\% and $20.2 \%$ of the cost of investing in the metro system ${ }^{15}$.

Although the estimated tax collection increase does not cover the investment costs of the new Line 4 of the Metro System, it should be noted that the estimated rise means a lower bound for various reasons. Firstly, the estimation assumes that new development projects will not be

\footnotetext{
${ }^{15}$ Assuming a 40 year useful life and an $8 \%$ discount rate (estimated useful life for the metro trains is 40 years and 100 years for infrastructure and rails).
} 
incorporated over the next 40 years. Secondly, the increase of 86,691 new housing units in the 1000 meter range of all Line 4 stations in the sample communes has not been considered. Thirdly, the increase in tax collection given the higher housing prices in La Granja, San Ramón, La Pintana, La Cisterna and El Bosque (communes which also have Line 4 stations in their range) has not been considered. Lastly, tax collection increase as the result of business licenses has not been included.

\section{Conclusions}

In general terms, investing in public transport infrastructure contributes to reduce traveling time and modifies consumer location preferences; in the medium or long run, urban conformation also changes.

In the city of Santiago, Chile, the Metro System is one of the most important investments in public transport infrastructure; in 2001, the government decided to considerably enlarge the metro coverage by extending Lines 2 and 4 and building a new Line 4 .

The construction of this new line has important effects for the city and has given way to different positive externalities; for this reason, an evaluation of its impact is important concerning public policy. The impact of the metro system brings about relevant effects on urban planning, public transport and fiscal policies. Additionally, from the point of view of the private sector, the mentioned impact means a very important sign for housing development projects.

This work has made use of an only a unique data base to study one of the many effects that building a new metro line brings about: the appreciation of the environment. In particular, by using a methodology that combines hedonic regressions and the estimation of average treatment effects, the degree of capitalization of access to the metro system on house prices has been estimated. Because the new Line 4 of the Santiago Metro is not yet operating, the estimated effects correspond to anticipated capitalization of this new line on apartment prices.

The results show a very important effect of the anticipated capitalization as the result of building a new metro line. The average value of the apartments rose between $3.3 \%$ and $4.4 \%$ 
after construction announcement and between $4.4 \%$ and $5.7 \%$ after the basic engineering project locating the stations was made known. The degree of capitalization depends on the distance to the closest metro station, decreasing at a rate between 0.06 and 0.14 UF for each meter farther away from the closest station.

A relevant aspect to consider in future extensions of the metro system is the likelihood of financing part of such extensions with a property tax rise that would allow the state, who indeed makes the investment, to capture the property value increase that results from building a new metro line.

\section{References}

Al-Mosaind, M.; Dueker, K.; y Strathman J. (1994). "Light Rail Transit Stations and Property Values: A Hedonic Price Approach”. Transportation Research Record 1400; 90-94.

Alonso, W. (1964). "Location and Land Use: Toward a General Theory of Land Rent". Cambridge, MA: Harvard University Press.

Angrist J., Imbens G. y Rubin D. (1996). "Identification of Causal Effects Using Instrumental Variables with Discussion”. Journal of the American Statistical Association 91, 444-472

Armstrong, R. (1994). "Impacts of Commuter Rail Service as Relected in Single-Family Residential Property Values”. Preprint, Transportation Research Board, 73 Annual Meeting.

Bajic, V. (1983). "The Effects of a New Subway Line on Housing Prices in Metropolitan Toronto". Urban Studies 20; 147-158.

Bartik, T. J. (1987). “The Estimation of Demand Parameter in Hedonic Price Models”. Journal of Political Economy 95; 81-8.

Blomquist, G., Berger, M. y Hoenh, J. (1988). "New Estimates of Quality of Life in Urban 
Areas". American Economic Review 78; 89-107.

Bowes, D. y Ihlanfeldt, K. (2001). "Identifying the Impacts of Rail Transit Stations on Residential Property Values". Journal of Urban Economics 50; 1-25.

Damm, D., Lerman, S., Lerner-Lam, E. y Young, J. (1980). "Response of Urban Real Estate Values in Anticipation of the Washington Metro". Journal of Transport Economics and Policy, September.

Debrezion, G., E. Pels y P. Rietveld (2003). “The Impact of Railway Stations on Residential and Commercial Property Value: A Meta Analisys”. Department of Spatial Economics, Free University. Amsterdam.

Dewees, D. N. (1976). “The Effect of a Subway on Residential Property Values in Toronto". Journal of Urban Economics 3; 357-369.

Dornbusch, D. (1975). "BART-Induced Changes in Property Values and Rents, in Land Use and Urban Development Projects, Phase I, BART: Final Report". U.S. Department of Transportation and U.S. Department of Housing and Urban Development. Working Paper WP 21-5-76.

Dueker, K., Chen, H., y Rufolo, A. (1998). "Measuring the Impact of Light Rail Systems on Single-Family Home Values". Transportation Research Record 1617; 38-43.

Freeman, A.M. (1979). "The Hedonic Approach to Measuring Demand for Neighbourhood Characteristics, in The Economics of Neighbourhood". Academic Press, New York.

Gatzlaff, D. y M. Smith (1993). "The Impact of the Miami Metrorail on the Value of Residences Station Locations". Land Economics 69; 54-66.

Gibbons, S. y Machin, S. (2005). "Valuing Rail Access Using Transport Innovations”. Journal of Urban Economics 57; 148-169. 
Gramlich, E.M. y D.L. Rubinfeld (1982), “Micro Estimates of Public Spending Demand Functions and tests of the Tiebout and Median-Voter Hypotheses. Journal of Political Economy 90, 536-560.

Grass, R. G. (1992). “The Estimation of Residential Property Values around Transit Station Sites in Washington, D.C.”. Journal of Economics and Finance 16; 139-146.

Gyourko, J. y Tracy, J. (1989). "Local Public Sector Rent-seeking and Its Impact on Local Land Values". Regional Science and Urban Economics 19; 493-516.

Gyourko, J. y Tracy, J. (1991). "The Structure of Local Public Finance and the Quality of Life". The Journal of Political Economy 99; 774-806.

Hamilton, B.W. (1976), “Capitalization of Intrajurisdictional Differences in Local Tax Prices”, American Economic Review 66, 743-753.

Heckman, J., Ichimura, H. y Todd, P. (1997). "Matching as an Econometric Evaluation Estimator: Evidence from Evaluating a Job Training Programme”. Review of Economic Studies 64; 605-54.

Lee, D. B. (1973). “Case Studies and Impacts of BART on Prices of Single Family Residences”. University of California, Institute of Urban and Regional Development, Berkeley, CA.

McDonald, J. y Osuji, C. (1994). "The effect of Anticipated Transportation Improvement on Residential Land Values". Regional Science and Urban Economics 25; 261-278.

McMillen, D. y McDonald, J. (2004). "Reaction of House Prices to a New Rapid Transit Line: Chicago’s Midway Line, 1983-1999”. Real Estate Economics 32; 463-486.

Mills, E. S. (1967). “Transportation and Patterns of Urban Development". American Economic Review 57; 197-210.

Muth, R. (1969). “Cities and Housing”. University of Chicago Press.

Roback, J. (1980). “The Value of the local Urban Amenities. Theory and Measurement”. P.h.D. 
dissertation, University of Rochester.

Roback, J. (1982). "Wages, Rents, and the Quality of Life”. Journal of Political Economy 90; 1257-78.

Rosen, S. (1974). "Hedonic Pricing and Implicit Markets: Product differentiation in Pure Competition”. Journal of Political Economy 82; 34-55.

Rosenbaum, P., and Rubin, D. B. (1983). "The Central Role of the Propensity Score in Observational Studies for Causal Effects”. Biometrika 70; 41-55.

Rubin, D. B. (1974). "Estimating Causal Effects of Treatments in Randomized and Nonrandomized Studies”. Journal of Educational Psychology 66; 688-701.

Rubinfeld, D. (1987), “The Economics of the Local Public Sector”, en el Handbook of Public Economics Vol. II, editado por A. Auerbach y M. Feldstein, Elsevier Science Publishers, 571-645.

Vesalli, K. (1996). "Land Use Impacts of Rapid Transit: A Review of the Empirical Literature". Berkeley Planning Journal 11; 71-105.

Voith, R. (1991). "Capitalization of Local and Regional Attributes Into Wages and Rents: Differences and Mixed-Use Communities”. Journal of Regional Science 31; 127-145.

Von Thünen, J. (1863) "Der Isolierte Staat in Beziehung auf Landwirschaft and Nationale Konomie". Munich: Pflaum.

Yinger, J. (1982), Capitalization and the Theory of Local Public Finance, Journal of Political Economy 90, 917-943. 